\title{
A novel carboxyl-terminal protease derived from Paenibacillus lautus CHN26 exhibiting high activities at multiple sites of substrates
}

Yunxia Li ${ }^{1}$, Yingjie Pan ${ }^{1}$, Qunxin She ${ }^{2}$ and Lanming Chen ${ }^{1 *}$

\begin{abstract}
Background: Carboxyl-terminal protease (CtpA) plays essential functions in posttranslational protein processing in prokaryotic and eukaryotic cells. To date, only a few bacterial ctpA genes have been characterized. Here we cloned and characterized a novel CtpA. The encoding gene, ctpAp (ctpA of Paenibacillus lautus), was derived from P. lautus CHN26, a Gram-positive bacterium isolated by functional screening. Recombinant protein was obtained from protein over-expression in Escherichia coli and the biochemical properties of the enzyme were investigated.

Results: Screening of environmental sediment samples with a skim milk-containing medium led to the isolation of a P. lautus CHN26 strain that exhibited a high proteolytic activity. A gene encoding a carboxyl-terminal protease (ctpAp) was cloned from the isolate and characterized. The deduced mature protein contains 466 aa with a calculated molecular mass of $51.94 \mathrm{kDa}$, displaying 29-38\% amino acid sequence identity to characterized bacterial CtpA enzymes. CtpAp contains an unusual catalytic dyad (Ser ${ }_{309}-$ Lys $\left._{334}\right)$ and a PDZ substrate-binding motif, characteristic for carboxyl-terminal proteases. CtpAp was expressed as a recombinant protein and characterized. The purified enzyme showed an endopeptidase activity, which effectively cleaved a S1- and $\beta$ - casein substrates at carboxyl-terminus as well as at multiple internal sites. Furthermore, CtpAp exhibited a high activity at room temperature and strong tolerance to conventional protease inhibitors, demonstrating that CtpAp is a novel endopeptidase.
\end{abstract}

Conclusions: Our work on CtpA represents the first investigation of a member of Family II CtpA enzymes. The gene was derived from a newly isolated P. lautus CHN26 strain exhibiting a high protease activity in the skim milk assay. We have demonstrated that CtpAp is a novel endopeptidase with distinct cleavage specificities, showing a strong potential in biotechnology and industry applications.

Keywords: CtpA, Paenibacillus, Protease, Aqueous environment

\section{Background}

CtpA proteins cleave peptide bonds at the carboxylterminus (C-terminus) of polypeptides, and are primarily involved in posttranslational protein processing, maturation or degradation in prokaryotic and eukaryotic cells [1]. These enzymes belong to an unusual type of serine peptidases that carry a catalytic dyad (Ser-Lys) at the

\footnotetext{
* Correspondence: Imchen@shou.edu.cn

${ }^{1}$ Key Laboratory of Quality and Safety Risk Assessment for Aquatic Products on Storage and Preservation (Shanghai), China Ministry of Agriculture, Engineering Centre for Quality Control and Risk Assessment of Aquatic Products, College of Food Science and Technology, Shanghai Ocean University, 999 Hu Cheng Huan Road, Shanghai 201306, People's Republic of China

Full list of author information is available at the end of the article
}

active site, instead of the well-known Ser-His-Asp catalytic triad commonly found in most serine proteases $[2,3]$. The first CtpA was described in Escherichia coli albeit under different identities: either as tail-specific protease (Tsp) or processing involving the C-terminal cleavage (Prc). This E. coli enzyme is an endopeptidase which cleaves peptide substrates containing apolar residues and a free $\alpha$-carboxylate at the C-terminus [4-6]. To date, CtpA enzymes have been characterized in some higher plants, algae, and bacteria [1]. In photosynthetic higher plants and cyanobacteria, CtpA is an essential peptidase in photosystem II (PS II) reaction center $[7,8]$, where the enzyme cleaves a precursor form of D1 protein, a key subunit of PS II, at C-terminal extension which 
consists of typically 9-16 amino acid residues [1]. Nonphotosynthetic bacterial CtpA enzymes exhibit a great diversity in sequence, suggesting that they have gained different functions during evolution. The E. coli CtpA is a protein with an apparent mass of about $80 \mathrm{kDa}$ in maxicell and in vitro systems [4]. The enzyme cleaves a periplasmic penicillin-binding protein 3 in E. coli and is involved in thermal and osmotic stresses and pathogenesis [4,9]. In Borrelia burgdorferi, CtpA processes outermembrane proteins P13 and BB0323 [10], whereas the same enzyme functions in bacterial biofilm formation in Rhizobium leguminosarum [11], and is involved in cell morphology and intracellular survival in Burkholderia mallei and Brucella suis [12,13]. Furthermore, biochemical traits of bacterial CtpA have indicated that these enzymes are resistant to a wide variety of conventional protease inhibitors $[5,14]$, which makes them potential good candidate proteases for biotechnology and industry application. Proteases constitute one of the three largest groups of industrial enzymes, accounting for about $60 \%$ of the total sales of enzymes worldwide [15], and they have been used in detergent, food, agrochemical and pharmaceutical industries [16]. Microorganisms are the main resources of hydrolases from which most commercial hydrolases are derived [17]. This is mainly because microbes exhibit much greater diversity than multicellular organisms (e.g. [18]).

As aquaculture industry is a fast developing area in China, sediments of aquaculture ponds have developed into novel environmental niches that are very rich in different nutrients, allowing diverse microbes to thrive. Recently a highly active esterase with exceptional resistance to organic solvents has been obtained from a sample collected from the environment [18]. Here we screened for protease-producing bacteria from sediment samples collected from the same fishery ponds in Shanghai, China, and found one of the isolates, Paenibacillus lautus $\mathrm{CHN} 26$, exhibited a high protease activity. A $\operatorname{ctp} A$ gene was cloned from this bacterium and expressed in E. coli using the pET-28a expression system. The resulting recombinant CtpA protein was purified and characterized. Our data indicated that $P$. lautus CtpA is a novel endopeptidase, exhibiting a strong application potential in biotechnology.

\section{Results and discussion}

\section{Screening and identification of a protease-producing bacterium}

We have developed a functional screening assay in which extracellular protease-producing bacteria form clear zones around their colonies on selective skim-milk agar plates (see the Methods). Employing the assay to screen for protease-producing bacteria from a sediment sample of fishery ponds identified several positive colonies, among which the isolate CHN26 produced very large clear zone of hydrolysis on the selective plate, suggesting that it could encode one or multiple highly active protease(s). Its $16 \mathrm{~S}$ rRNA gene was amplified by polymerase chain reaction (PCR) using the $27 \mathrm{~F}$ and $1492 \mathrm{R}$ primers, and the gene sequence was determined (GenBank: KF460030). Database searches with the 16S rRNA gene revealed that it displayed 96-99\% nucleotide sequence identity with the corresponding genes derived from dozens of Paenibacillus bacteria. The phylogenetic position of the isolate was studied by comparing the $16 \mathrm{~S}$ rRNA gene sequence with a selected set of Paenibacillus bacteria retrieved from the GenBank databases and a phylogenetic tree was constructed using the MEGA4.0 (Figure 1). Strain CHN26 fell into the clade of P. lautus, suggesting it was closely related to this species.

Bacteria of Paenibacillus species are widespread: they have been isolated from different environments including soil, plant, insect and aqueous samples. A very striking feature for these bacteria is that they exhibit great versatility in metabolic capacities. These bacteria produce various extracellular enzymes such as polysaccharide-degrading enzymes and proteases, several of which have shown strong potential in industrial applications [19-23].

Characterization of the $P$. lautus CHN26 revealed the following: Cells of this organism are Gram-positive rods, oxidase- and catalase-positive, and form transparent nonpigmented colonies on nutrient agar media. It grows optimally at $30^{\circ} \mathrm{C}, \mathrm{pH} 7.5$ and in the presence of $3 \% \mathrm{NaCl}$. This strain was negative in the Indole test, and did not produce $\mathrm{H}_{2} \mathrm{~S}$. Neither did it hydrolyze or utilize starch,

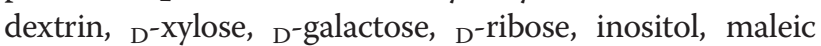
acid or sodium succinate. The bacterium was tested positive in the Voges-Proskauer, and methyl-red assays. More importantly, it could grow in the medium containing $\alpha / \beta$

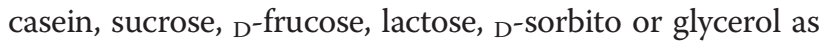
the sole energy (Table 1). In summary, this isolate showed a few distinct features such as utilization of $\mathrm{D}^{\text {-sorbito and }}$ citrate, Voges-Proskauer test, $\mathrm{H}_{2} \mathrm{~S}$ production and nitrite reduction, which deviated itself from the other known P. lautus strain [24].

\section{Molecular cloning of a ctpA gene in Paenibacillus lautus CHN26}

We were interested in studying proteases encoded in this bacterium. Recently, the complete genome of Paenibacillus sp.Y412MC10 was reported (GenBank: NC_013406.1) [25]. To gain an insight into what gene product could be responsible for the hydrolytic activity of $P$. lautus $\mathrm{CHN} 26$ in the skim milk assay, a few putative protease genes of Paenibacillus were investigated, in which the C-terminal protease could be responsible for the observed activity (see below).

$P$. lautus encodes only one putative C-terminal protease, although many other Bacillus species (e.g. B. subtilis) 
Figure 1 Phylogenetic anlysis of 16S rRNA gene sequences of all Paenibacillus species showing that the newly isolated CHN26 is most closely related to Paenibacillus lautus. Bootstrap percentages are shown at nodes. The scale bar represents 0.02 changes per nucleotide. The GenBank accession numbers are shown behind the names of the strains, and the strain identified in this study is marked with a solid triangle. 
Table 1 Phenotypic features of the P. lautus CHN26

\begin{tabular}{|c|c|}
\hline Features & Paenibacillus lautus CHN26 \\
\hline Gram-staining & Positive \\
\hline Cell size $(\mu \mathrm{m})$ & $2-5 \mathrm{~mm}$ \\
\hline Colony colour and morphology & $\begin{array}{l}\text { No pigment, circular, smooth, } \\
\text { slightly convex, margin entire, }\end{array}$ \\
\hline Temperature for growth $\left({ }^{\circ} \mathrm{C}\right)$ & 15-40, optimum: 30 \\
\hline $\mathrm{pH}$ for growth & 5.5-8.5, optimum: 7.5 \\
\hline $\mathrm{NaCl}$ concentration for growth $(\%, w / v)$ & 1-5, optimum: 3 \\
\hline Hydrolysis of starch & - \\
\hline $\begin{array}{l}\text { Assimilation of: L-arabinose, Citrate, } \\
\text { D-glucose, maltose }\end{array}$ & + \\
\hline \multicolumn{2}{|l|}{ Utilization of: } \\
\hline$A / \beta$ casein & + \\
\hline Sucrose, D-frucose, lactose, D-sorbito & + \\
\hline D-xylose, D-ribose, D-galactose, & - \\
\hline Sodium succinate, inositol, maleic acid & - \\
\hline Glycerol & + \\
\hline $\begin{array}{l}\text { Voges-Proskauer test, methyl-red test, } \\
\mathrm{H}_{2} \mathrm{~S} \text { production, oxidase, gelatin } \\
\text { liquefaction, nitrite reduction, } \\
\text { phenylalanine deaminase, }\end{array}$ & + \\
\hline Indole test, producion of dextrin & - \\
\hline
\end{tabular}

$a_{+}$: positive reaction; -:negative reaction.

encodes two, namely CtpA and CtpB. A few CtpB enzymes have been characterized and it has been shown that these enzymes play important functions in cellular process such as sporulation [26]. However, to our knowledge, none of CtpA enzymes derived from a Gram-positive bacterium have been characterized thus far.

The ctpA gene from $P$. lautus CHN26 was amplified using the primer pair ctp1-F and ctp1-R (see the Methods) targeting the corresponding gene sequence of Paenibacillus sp.Y412MC10 (GenBank: NC_013406.1), which was re-classed as $P$. lautus recently $[24,25]$. A PCR product of the expected size $(1.4 \mathrm{~kb})$ was obtained from $P$. lautus CHN26, and the $\operatorname{ctp} A$ gene sequence of $P$. lautus CHN26 was determined (GenBank: KF169841): an open reading frame of $1,473 \mathrm{bp}$ encoding a protein of 490 aa with a calculated molecular mass of $53.92 \mathrm{KDa}$. The deduced amino acid sequence displayed high sequence identities to putative C-terminal proteases encoded in Paenibacillus species (53-99\% identity), all of which have not been characterized. Furthermore, $P$. lautus CtpA showed relatively lower sequence similarities (29-38\% identities) to all characterized bacterial CtpA proteins, including those encoded in E. coli, Bartonella bacilliformis, B. burgdorferi, B. suis, B. mallei, and Pseudomonas aeruginosa [4,12,13,27-29]. These CtpA sequences were retrieved from the GenBank database and analyzed by multiple sequence alignments. This analysis revealed that CtpA of the P. lautus (CtpAp) contains the catalytic dyad ( $\operatorname{Ser}_{309}$-Lys $\left._{334}\right)$ and substratebinding $\mathrm{B}$ domain, also designated as PDZ motif [2,3], both of which are highly conserved in all known CtpA proteins (Figure 2).

The multiple sequence alignments were also used to construct phylogenetic trees to gain an insight to their diversity and classification. This analysis revealed three families for CtpA enzymes, namely Family I, II, and III (Figure 3). The CtpA enzymes of E. coli and $P$. aeruginosa belong to family I, the enzymes encoded in $B$. bacilliformis, B. burgdorferi, B. suis, B. mallei and Synechocystis sp. fall into Family III, whereas CtpAp forms family II with several CtpA entries identified in the GenBank databases. Notably, family II of CtpA proteins are derived from diverse bacterial species phylogenetically distantly related.

\section{Expression and purification of the CtpAp protein in E. coli BL21}

The ctpAp structural gene (1398-bp, excluding the first 72-bp signal peptide sequence of the 5 -terminus and the stop codon) was amplified with the primer pair ctp1F2 and ctp1-R2 (see the Methods). The PCR product was cloned into the expression vector pET-28a, giving pET28a-ctpAp. The expression plasmid was transformed into E. coli BL21, and $\operatorname{Kan}^{\mathrm{r}}$ transformants were screened by colony PCR to test for the presence of pET28a-ctpAp. Positive transformants were cultured in LB-kanamycin medium, and the expression of $\operatorname{ctpAp}$ gene was analyzed by SDS-PAGE. As presented in Figure 4 (lane 3), one band appeared at the size corresponding to the calculated molecular mass of CtpAp in the pET28a-ctpAp transformant, but absent from the E. coli BL21 cells carrying pET28a (Figure 4, lane 2), suggesting that the protein band represented the recombinant CtpAp resulting from episomic ctpAp expression.

The recombinant CtpAp protein with twelve his-tags was purified by affinity purification via a Ni-NTA His Bind resin column. Then, the purified enzyme was concentrated and desalted using an Amicon Ultra-15 centrifugal filter device. Figure 4 (lane 4) shows the purified CtpAp protein with an apparent molecular mass of approximately $52 \mathrm{KDa}$, giving a protein yield of about $50.64 \mathrm{mg}$ of per $1 \mathrm{~g}$ wet biomass and a relative activity of $764.78 \mathrm{U} / \mathrm{mg}$ protein using $\beta$-casein as the substrate.

\section{Substrate specificity of the $P$. lautus CtpA enzyme}

To examine protease activity of the recombinant CtpAp protein, E. coli BL21 strain harboring the expression plasmid pET28a-ctpAp was streaked on the skim milk agar plates containing $30 \mu \mathrm{g} / \mathrm{ml}$ kanamycin and IPTG, and incubated at $37^{\circ} \mathrm{C}$ for $36 \mathrm{~h}$. Clear zones of hydrolysis around the pET28a-ctpAp transformant appeared on the selective agar plates. The colonies of $E$. coli BL21 containing 


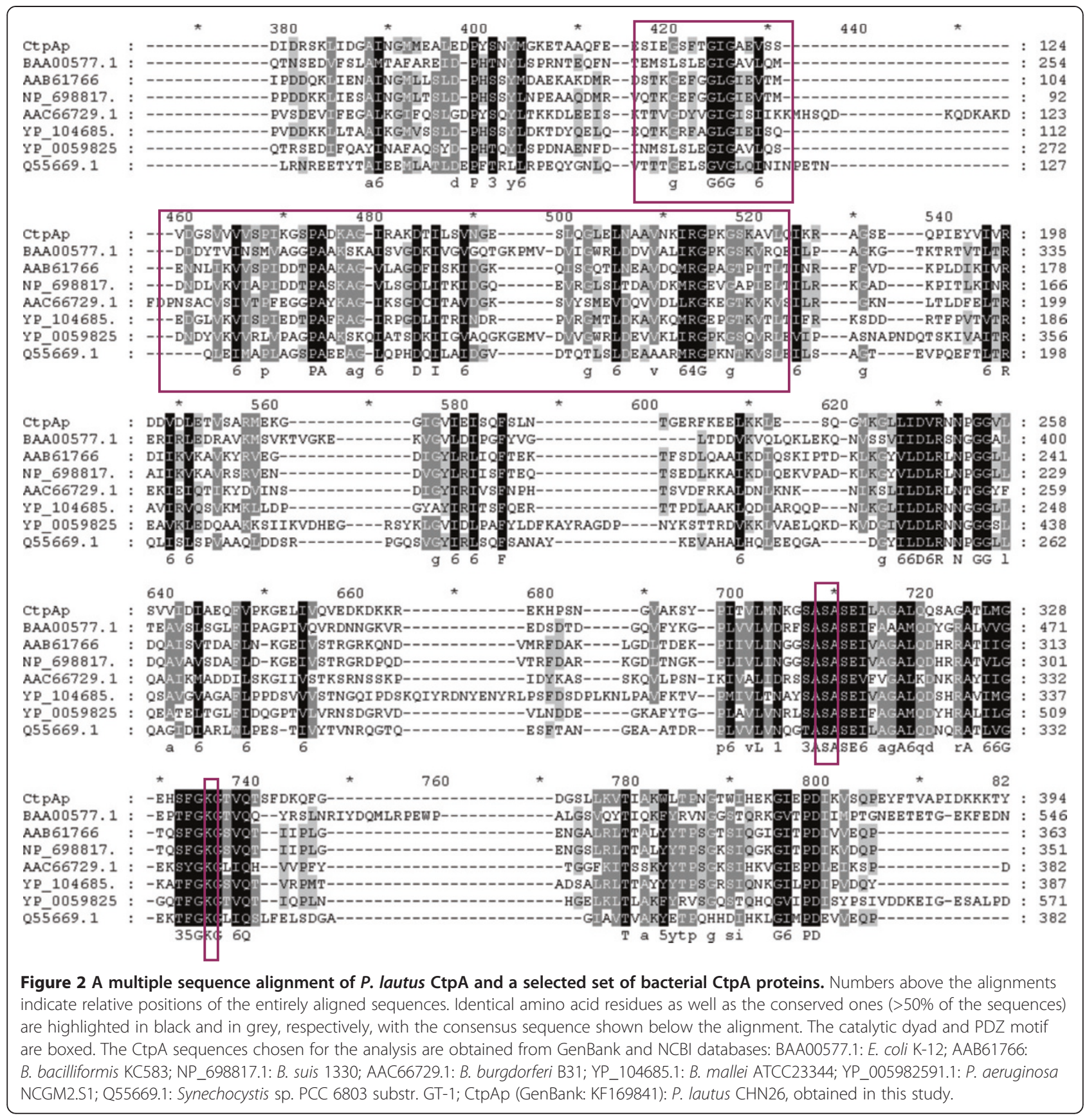

only pET28a did not form any clear zones in the skim milk assay (data not shown).

The purified CtpAp enzyme was then assayed for proteolytic activity using two different casein substrates, $\beta$-casein and $\alpha$ S1-casein. The purified enzyme was incubated with each substrate at $30^{\circ} \mathrm{C}$ for $0.5-6 \mathrm{~h}$, and reaction products were analyzed by SDS-PAGE. As shown in Figure 5, CtpAp cleaved $\beta$-casein into shorter fragments (Figure 5, Lane 6-10) as for other bacterial CtpA enzymes (e.g. Spiers et al., 2002). Notably, $\alpha$ S1casein appeared to serve as a better substrate for CtpAp degradation than $\beta$-casein, as the reaction with the former substrate was ca. 3-fold faster than the degradation of the latter substrate under the same reaction condition (Figure 5, Lane 2-4). This result is in a good agreement with the high protease activity of $P$. lautus $\mathrm{CHN} 26$ in the skim milk assay since $\alpha$ S1-casein is a predominant component of the substrates in the assay.

To reveal the cleavage sites of CtpAp on the casein substrates, we analyzed the digest products using a matrix-assisted laser desorption and ionization time of flight mass spectrometer (MALDI-TOF MS) with the 


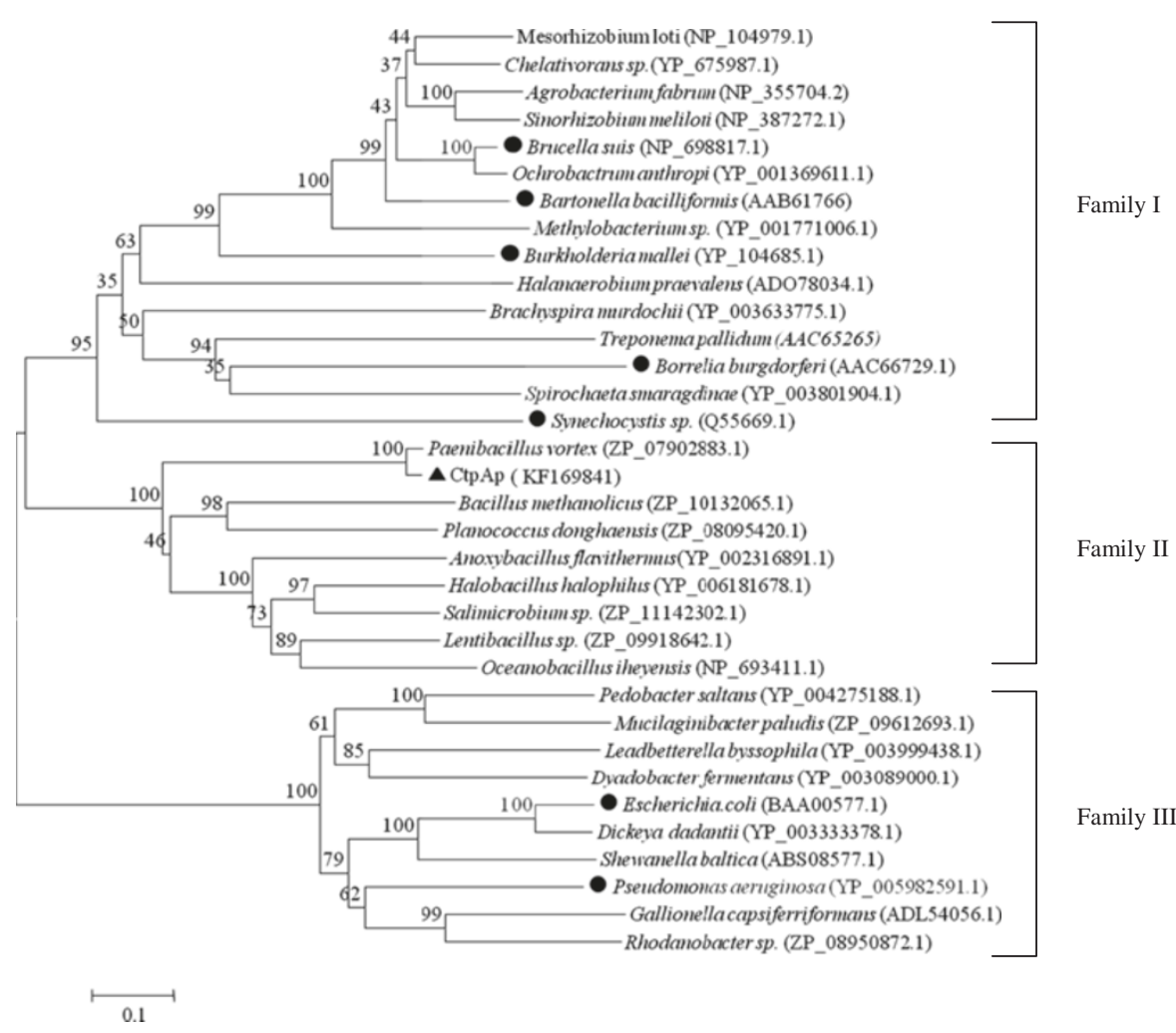

Figure 3 Phylogenetic tree showing evolutionary relationship between the P. lautus CtpA and all characterized bacterial CtpA and related proteins. A neighbor-joining phylogenetic tree was constructed using MEGA 4.0. Bootstrap percentages are shown at nodes. The scale bar represents 0.1 changes per amino acid. Filled cycles denote the bacterial CtpA proteins that have been characterized for their activity and function, whereas $P$. lautus CtpA identified in this study is marked with a solid triangle.

resulting data summarized in Table 2. CtpAp cleavage of both substrates yielded multiple peptide fragments of different sizes, suggesting that cleavage by CtpAp lacked stringency in site selection on each substrate. CtpAp cleaved $\beta$-casein (224 aa residues, Swiss-Prot: P02666.2) [30] at four sites at the C-terminus, including $\mathrm{Glu}_{210^{-}}$ $\mathrm{Pro}_{211}, \mathrm{Leu}_{213}-\mathrm{Gly}_{214}, \mathrm{Gly}_{214}-\mathrm{Pro}_{215}$ and $\mathrm{Pro}_{215}-\mathrm{Val}_{216}$, all of which are apolar amino acid residues. It has been reasoned that CtpA enzymes rely on the recognition of scissile bonds at $\mathrm{C}$-terminus of the substrates for $\mathrm{C}$ terminal protease activity, giving typically oligopeptide products of 9-14 residues. Such cleavage preferences have been reported previously for $E$. coli CtpA enzyme [4-6]. Similarly, for the $\alpha$ S1-casein substrate of 214 aa (GenBank: 1308122A) [31], the enzyme recognized three peptide bonds at $\mathrm{C}$-terminus and produced oligopeptides of 7-9 aa. However, interesting differences in site selection on $\alpha$ S1-casein were observed: all three cleavage sites of CtpAp contain polar residues at C-terminus of the substrate $\left(\mathrm{Asn}_{205}-\mathrm{Ser}_{206}, \mathrm{Ser}_{206}-\mathrm{Glu}_{207}\right.$ and $\mathrm{Glu}_{207^{-}}$ Lys $_{208}$ ), namely Asn, Ser and Lys, which is in contrast to its site selection on $\beta$-casein where only nonpolar residues are sites of cleavage (see above).
In addition, CtpAp also cleaved at six sites on $\beta$-casein located more distantly from the $\mathrm{C}$-terminus, including $\mathrm{Ala}_{15}-\mathrm{Arg}_{16}, \mathrm{Gln}_{69}-\mathrm{Thr}_{70}, \mathrm{Val}_{107}-\mathrm{Met}_{108}, \mathrm{Gln}_{175}-\mathrm{Ser}_{176}$, $\mathrm{Gln}_{175}-\operatorname{Ser}_{176}$ and $\mathrm{Gln}_{182}-\mathrm{Ser}_{183}$. Such internal cleavage also occurred for the $\alpha$ S1-casein substrate where five active sites were revealed for CtpAp cleavage, including $\mathrm{Leu}_{35}-\mathrm{Leu}_{36}, \mathrm{Phe}_{38}-\mathrm{Phe}_{39}, \mathrm{Asn}_{53}-\mathrm{Glu}_{54}, \mathrm{Ser}_{130}-\mathrm{Ala}_{131}$ and $\mathrm{Ala}_{131}-\mathrm{Glu}_{132}$. To our knowledge, among all CtpA enzymes characterized to date, the E. coli CtpA represents the only one that also cleaves its substrate at multiple sites [6]. Furthermore, the two CtpA enzymes show a great diversity in internal cleavage sites: the only site that is in common for them is $\mathrm{Ala}_{15}-\mathrm{Arg}_{16}$. Such functional diversity of CtpA enzymes is often advantageous for their application in biotechnology.

In contrast, several known CtpA enzymes have showed strong stringencies in site selection of peptide cleavage. For example, the amino acid residues (Ala-Ala / Ser) at the cleavage sites of $\mathrm{C}$-terminus extension in $\mathrm{pD} 1$ are very well conserved in photosynthetic organisms $[1,32]$. We also tested CtpAp cleavage on this substrate using a synthetic oligopeptide (S24) comprising 24 aa $\left(\mathrm{Val}_{330}\right.$ to $\mathrm{Gl}_{3_{353}}$ ) of the pD1 C-terminus. Incubation of the S24 


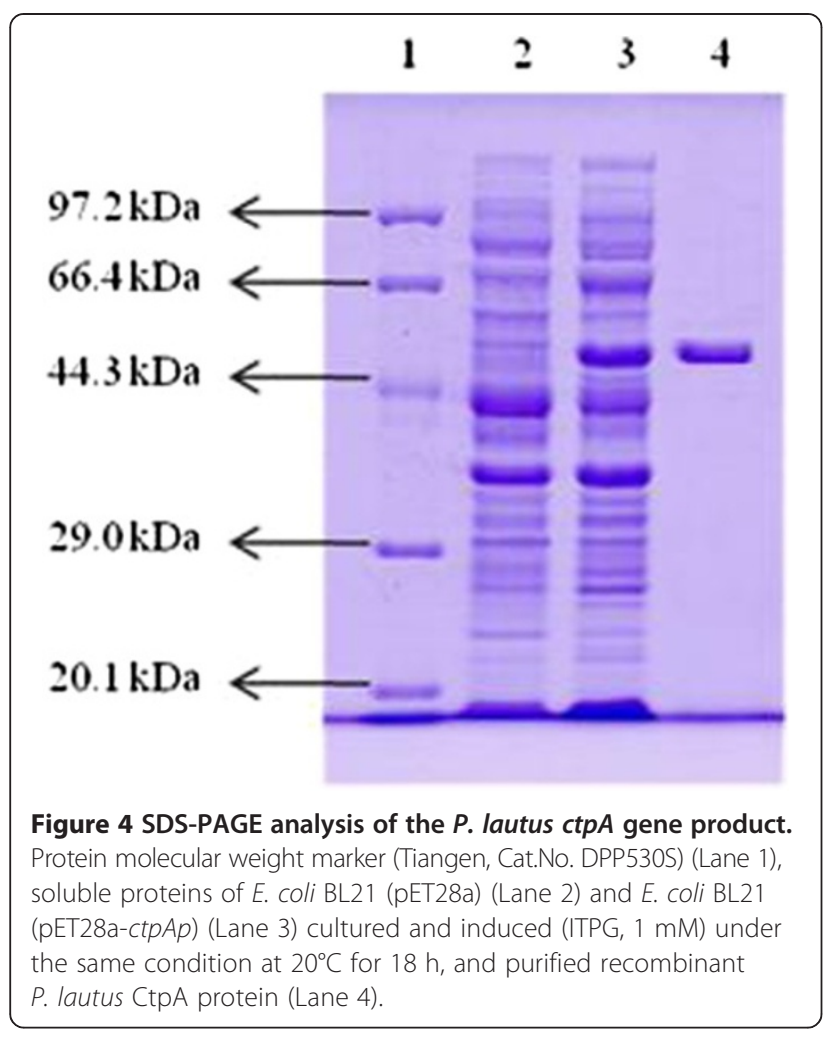

substrate with CtpAp at $30^{\circ} \mathrm{C}$ for $3 \mathrm{~h}$ revealed that this bacterial CtpA enzyme partially broke down the substrate, yielding N15 and C9 oligopeptides (Figure 6C). However, CtpAp appears to be much less active on S24 than that on the casein substrates. In addition, CtpAp failed to show any detectable haemolytic activity. Taken together, CtpA enzymes fall into two distinct categories, in regard of site selection stringency. Photosynthetic CtpA enzymes exhibit strong amino acid sequence specificity and play important cellular functions, whereas nonphotosynthetic CtpAs, such as the E. coli CtpA and CtpAp do not show a strong site preference in cleavage, and these enzymes degrade their substrates at multiple sites. Apparently, CtpA enzymes of the latter category show a strong application potential in protein degradation at an industrial level.

\section{Effect of temperature and $\mathrm{pH}$ on $\mathrm{P}$. lautus CtpA activity and stability}

The temperature profile of CtpAp was determined for the temperature range of $10^{\circ} \mathrm{C}$ to $80^{\circ} \mathrm{C}$ at $\mathrm{pH} 9.0$ using $\beta$ casein as a substrate. As illustrated in Figure 7A, CtpAp displayed maximum enzyme activity at $30^{\circ} \mathrm{C}$, retaining up to $95.6 \%$ of its initial activity at $20-35^{\circ} \mathrm{C}$. The enzyme activity decreased steeply as the temperature increased above $50^{\circ} \mathrm{C}$, indicating that the CtpAp is a mesophilic enzyme.

To examine the effect of temperature on CtpAp stability, aliquotes of the purified enzyme were incubated at various temperatures for $3 \mathrm{~h}$, and the residual activity of the treated protein was assayed at $30^{\circ} \mathrm{C}, \mathrm{pH}$ 9.0. As shown in Figure 7B, CtpAp exhibited considerable stability and retained more than $95 \%$ of its initial activity after treatment at $10-30^{\circ} \mathrm{C}$ for $3 \mathrm{~h}$. Treating the enzyme at $50^{\circ} \mathrm{C}$ resulted in residual activity of $58 \%$, and further elevating pretreated temperature $\left(60-80^{\circ} \mathrm{C}\right)$ yielded a steep reduction of the enzyme activity, suggesting that CtpA is a mesophilic enzyme.

The effect of $\mathrm{pH}$ on CtpAp activity and stability was studied at $30^{\circ} \mathrm{C}$, the optimal reaction temperature. As shown in Figure $7 \mathrm{C}$, the enzyme displays a high activity at $\mathrm{pH}$ 8.09.0. The residual activity declined sharply at either higher $\mathrm{pH}$ or lower $\mathrm{pH}$ values. The similar $\mathrm{pH}$ dependency of enzyme activity has been reported for other recombinant CtpA enzymes $[1,33]$. The effect of $\mathrm{pH}$ on enzyme stability was assayed by pre-incubating the purified CtpAp at various $\mathrm{pH}$ values for $12 \mathrm{~h}$ at $4^{\circ} \mathrm{C}$. As shown in Figure 7D, CtpAp exhibited considerable stability at $\mathrm{pH}$ 8.0-9.0. However, the enzyme activity diminished more than 50\% after prolonged incubation in either more acidic (< $\mathrm{pH6.0)}$ or more alkaline (> pH11.0) conditions.

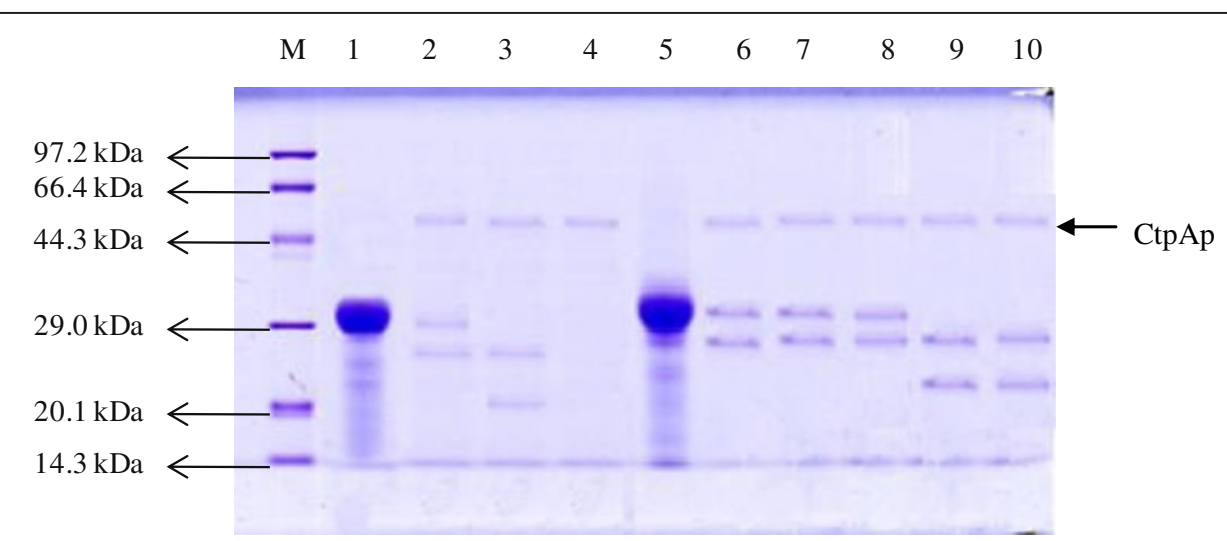

Figure 5 SDS-PAGE analysis of degradation of the casein substrates by P. lautus CtpA. Protein molecular weight marker (Tiangen, Cat.No. DPP530S) (Lane M); The a S1-casein (Lane 1) was incubated with CtpAp at $30^{\circ} \mathrm{C}$ for 0.5 (Lane 2), 1 (Lane 3) and $1.5 \mathrm{~h}$ (Lane 54), respectively; while the $\beta$-casein (Lane 5) with the enzyme at 30 ${ }^{\circ} \mathrm{C}$ for 0.5 (Lane 6), 1 (Lane 7), 2 (Lane 8), 4 (Lane 9) and $6 \mathrm{~h}$ (Lane 10), respectively. 
Table 2 Cleavage of $\beta$ and a S1-casein substrates by the $P$. lautus CtpA determined by MALDI-TOF MS

\begin{tabular}{|c|c|c|c|c|}
\hline Substrates & Monoisotopic mass of neutral peptide Mr (cal) & Sequences & Cleavage sites & Expect value \\
\hline \multirow[t]{10}{*}{$\beta$-casein } & 1624.8308 & A $\downarrow$ RELEELNVPGEIVE & $\mathrm{Ala}_{15}-\operatorname{Arg}_{16}$ & 0.000038 \\
\hline & 1528.7926 & Q\TQSLVYPFPGPIPN & $\mathrm{Gln}_{69}-\mathrm{Thr}_{70}$ & 0.0011 \\
\hline & 1299.6863 & Q\SLVYPFPGPIPN & $\mathrm{Gln}_{71}-\mathrm{Ser}_{72}$ & 0.00003 \\
\hline & 876.4739 & V\MGVSKVKE & Val $_{107}-$ Met $_{108}$ & 0.027 \\
\hline & 947.5287 & Q\SVLSLSQSK & $\mathrm{Gln}_{175}-\operatorname{Ser}_{176}$ & 0.0015 \\
\hline & 994.6175 & Q\SKVLPVPQK & $\mathrm{Gln}_{182}-\operatorname{Ser}_{183}$ & 0.0027 \\
\hline & 1459.8915 & E\PVLGPVRGPFPIIV & $\mathrm{Glu}_{210}-\mathrm{PrO}_{211}$ & 0.0037 \\
\hline & 1150.6863 & 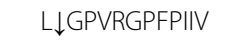 & Leu $_{213}$-Gly 214 & 0.0022 \\
\hline & 1093.6648 & G】PVRGPFPIIV & $\mathrm{Gly}_{214}$-PrO 215 & 0.00011 \\
\hline & 996.6120 & P\VRGPFPIIV & $\operatorname{Pro}_{215}-\mathrm{Val}_{216}$ & 0.0061 \\
\hline \multirow[t]{8}{*}{ a S1-casein } & 1467.7915 & 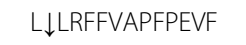 & $\mathrm{Leu}_{35}-\mathrm{Leu}_{36}$ & 0.016 \\
\hline & 1051.5379 & F\FVAPFPEVF & $\mathrm{Phe}_{38}-\mathrm{Phe}_{39}$ & 0.0011 \\
\hline & 760.3967 & N\ELSKDIG & $\mathrm{Asn}_{53}-\mathrm{Glu}_{54}$ & 0.0041 \\
\hline & 753.3769 & S\AEERLH & $\operatorname{Ser}_{130}-$ Ala $_{131}$ & 0.00092 \\
\hline & 1157.5499 & $A \downarrow E E R L H S M K E$ & Ala $_{131}-\mathrm{Glu}_{132}$ & 0.000021 \\
\hline & 1107.5270 & N\SEKTTMPLW & $\mathrm{Asn}_{205}-\mathrm{Ser}_{206}$ & 0.00045 \\
\hline & 1004.5001 & S\EKTTMPLW & $\mathrm{Ser}_{206}-\mathrm{Glu}_{207}$ & 0.00015 \\
\hline & 875.4575 & E\KTTMPLW & Glu $_{207-L_{2}}$ & 0.0026 \\
\hline
\end{tabular}

To date, very few previous researches have reported activity of proteases at room temperature [34]. The high activity at room temperature and stability at an alkaline $\mathrm{pH}$ render CtpAp as an ideal enzyme in a range of industry application.

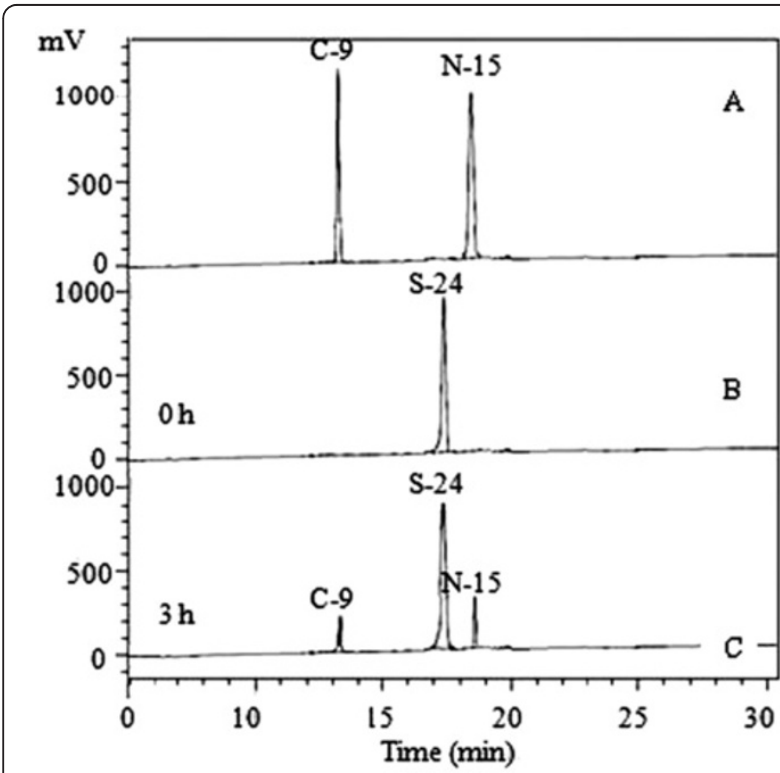

Figure $6 \mathrm{HPLC}$ analysis of specific cleavage of the C-terminal oligopeptide of pD1 by P. lautus CtpA. The S24 substrate (B) corresponding to the 24 aa residues at the $\mathrm{C}$-terminus of $\mathrm{pD} 1$ was incubated with CtpAp at $30^{\circ} \mathrm{C}$ for $3 \mathrm{~h}$, yielding two products $\mathrm{N}-15$ and $\mathbf{C}-9$ oligopeptides (C) matching the 15 and 9 residues at the $\mathrm{N}$ and C-terminus of the S24 (A), respectively.
Effect of metal ions and protease inhibitors on $P$. lautus CtpA activity

To address the effect of metal ions on CtpA activity, aliquotes of the purified enzyme were individually incubated with $\mathrm{ZnCl}_{2}, \mathrm{CaCl}_{2}, \mathrm{MgCl}_{2}, \mathrm{BaCl}_{2}, \mathrm{CuCl}_{2}$, $\mathrm{MnCl}_{2}$ and $\mathrm{KCl}$ at $1-10 \mathrm{mM}$ concentration at $30^{\circ} \mathrm{C}$ for $1 \mathrm{~h}$, and residual activities were measured under the standard assay condition (Figure 8). Comparing to the control, $\mathrm{Mn}^{2+}$ and $\mathrm{Ca}^{2+}$ elevated CtpA activity by $59.6 \%$ and $32.8 \%$, respectively, whereas $\mathrm{Ba}^{2+}, \mathrm{Cu}^{2+}$ and $\mathrm{Zn}^{2+}$ strongly inhibited enzyme activity, reducing the activity by $30-50 \%$. These results resemble those reported for E. coli CtpA [5].

Tolerance to metal chelator (EDTA) and protease inhibitors is very important for any enzymes to be explored in industrial application. As shown in Figure 8, CtpAp displayed remarkable resistance to the conventional inhibitors of serine proteases, as no loss of activity was observed after treating the enzyme with phenylmethanesulfonyl fluoride (PMSF, 1-10 mM) or diisopropyl fluorophosphate (DFP, 1-10 $\mathrm{mM}$ ), indicating that the enzyme belongs to an unusual type of serine proteases. Protease inhibitor tolerance has been reported for E. coli CtpA [5]. However, CtpAp showed much stronger tolerance to the inhibitors tested, since it retained the maximal activity at inhibitor concentrations that were 5-20-fold higher than those reported for E. coli enzyme, further arguing for the diversity in biochemical properties of CtpA enzymes. In addition, treating the enzyme with $10 \mathrm{mM}$ EDTA did not yield any effect 

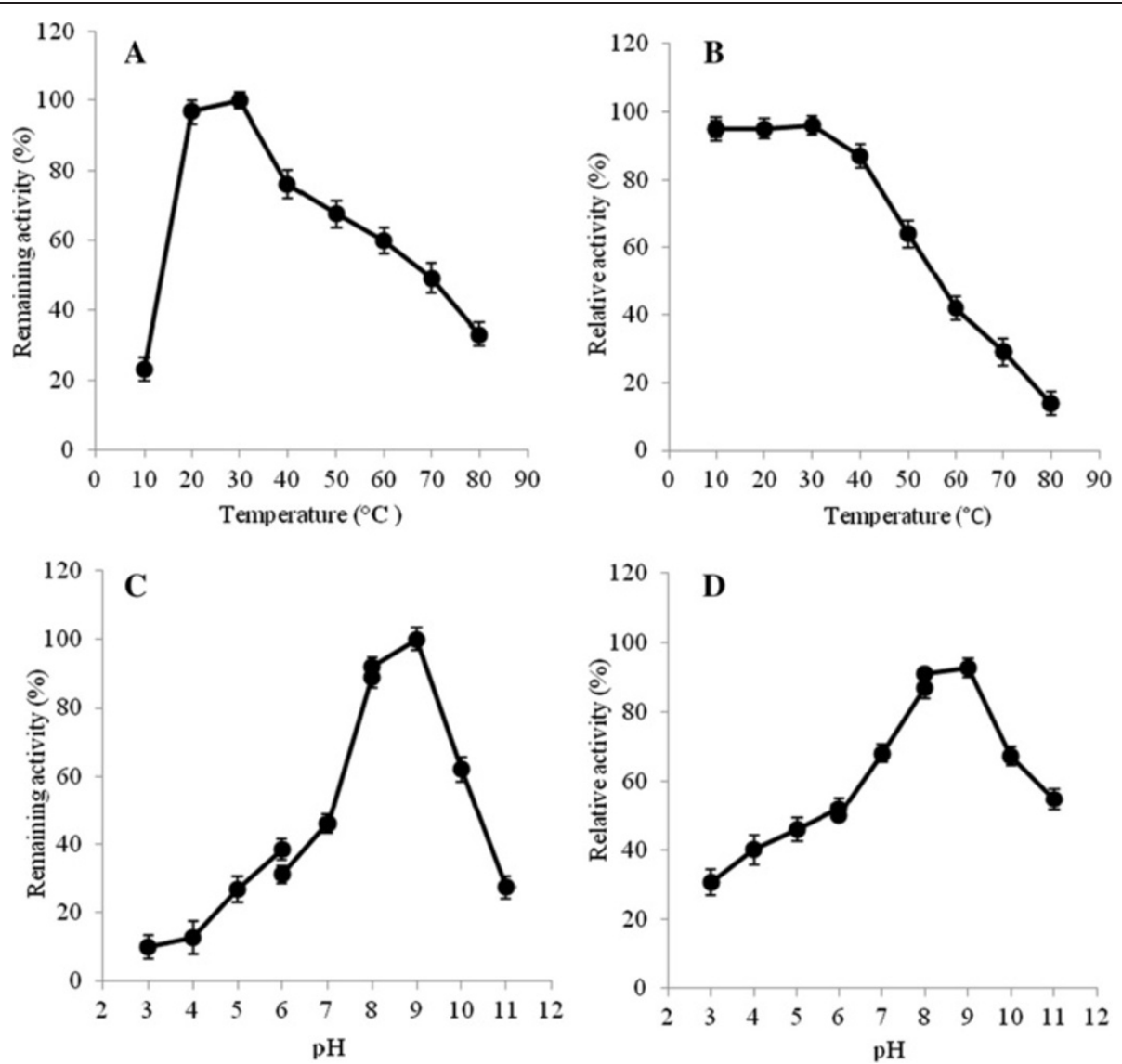

Figure 7 Effect of temperature and pH on P. lautus CtpA enzyme activity and stability. Relative activity of purified CptAp was determined at different temperatures (A) or $\mathrm{pH}$ (C) using $\beta$-casein as the substrate at $562 \mathrm{~nm}$. Remaining enzyme activity was measured at $30^{\circ} \mathrm{C}$ and $\mathrm{pH} 9.0$ after incubating purified CtpAp at different temperatures for $3 \mathrm{~h}$ (B), or $\mathrm{pH}$ at $4^{\circ} \mathrm{C}$ for $12 \mathrm{~h}$ (D). All determinants were performed in triplicate.

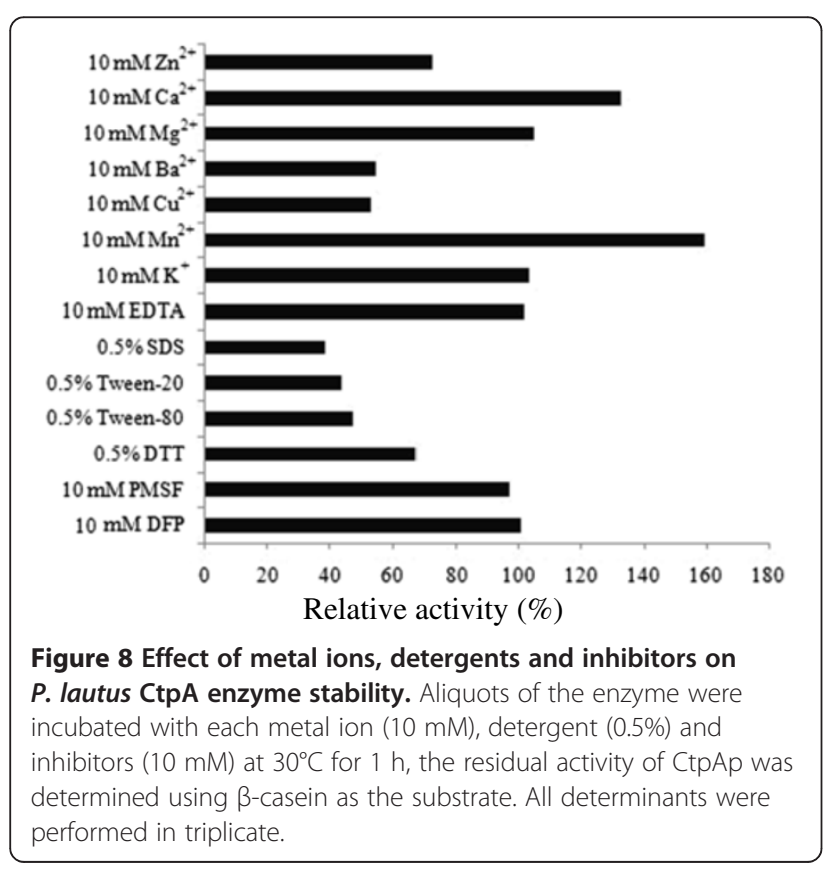

on the enzyme activity, suggesting that CtpAp is not a metalloprotease.

\section{Effect of detergents and organic solvents on P. lautus CtpA activity}

In contrast to distinct stability of CtpAp in the presence of protease inhibitors, detergents including sodium dodecyl sulfate (SDS), Tween 20 and Tween 80 greatly inhibited the enzyme activity, reducing about $53-62 \%$ of its activity at a final concentration of $0.5 \%$ (Figure 8). Likewise, CtpAp was also sensitive to all the organic solvents tested in this study including acetone, acetonitrile, 1-butanol, ethanol, methanol, 2-propanol, dimethyl sulfoxide (DMSO) and dimethylformamide (DMF), as it lost $42-72 \%$ activity under the treatments with each of the organic solvents at a final concentration of $1 \%$ (data not shown).

\section{Conclusions}

In this study, a novel carboxyl-terminal protease gene was identified from a newly isolated Paenibacillus lautus 
CHN26 strain, designated $\operatorname{ctpAp}$. This gene encodes a mature protein of 466 aa with a calculated molecular mass of $51.94 \mathrm{kDa}$, displaying $29-38 \%$ amino acid sequence identity to a few characterized bacterial CtpA enzymes. CtpAp was expressed as a recombinant protein in Escherichia coli BL21 using the pET expression system. The purified CtpAp protein displayed endopeptidase activity, and it effectively cleaves $\beta$ - and $\alpha$ S1- casein substrates at either $\mathrm{C}$-terminal or multiple internal sites. Comparing CtpAp with other characterized CtpA proteins revealed interesting diversity in their cleavage site selection, and CtpAp also exhibited high activity at a room temperature with strong tolerance to protease inhibitors. The distinct biochemical properties positioned CtpAp as a novel endopeptidase with an application potential in industry and biotechnological applications.

\section{Methods}

Bacterial strains, plasmids, media and culture conditions Escherichia coli TOP10 [genotype: F mcrA $\Delta$ (mrr-hsdRMSmcrBC) $\psi 80$ lacZ $\Delta \mathrm{M} 15 \Delta$ lacX74 recA1 araD139 (ara-leu) 7697 galU galK rpsL(Str ${ }^{\mathrm{r}}$ ) endA1 nupG] (TianGen Biotech Co. Ltd. Beijing, China) was used as a host strain for DNA cloning. E. coli BL21 (DE3) [genotype: $\mathrm{F}^{-}$omp $\mathrm{T}$ hsd $\mathrm{S}_{\mathrm{B}}\left(r_{\mathrm{B}}^{-} m_{\mathrm{B}}^{-}\right)$gal $d c m(\mathrm{DE} 3)$ ] (Tiangen) was employed as a host for expression of recombinant proteins. The plasmid pGM-T (TianGen) and pET-28a (Merck Millipore, Darmstadt, Germany) were used as vectors for TA cloning and recombinant protein expression, respectively. E. coli was routinely grown in Luria-Bertani (LB) medium [35] at $37^{\circ} \mathrm{C}$ with shaking at $200 \mathrm{rpm}$, while E. coli strains containing recombinant plasmids were cultured in LB broth or agar plates supplemented with ampicillin $(100 \mu \mathrm{g} / \mathrm{ml})$ or kanamycin $(30 \mu \mathrm{g} / \mathrm{ml})$.

The skim milk agar medium [36] containing 2\% (w/v) skim milk (Baomanbio Co. Ltd, Shanghai, China) was used in the skim milk assay to screen for protease-producing isolates. Blood Agar Plates containing 8\% (v/v) Defiber sheep blood (Truelab Biotech Co. Ltd, Shanghai, China) was used for haemolysis assay.

\section{Isolation and characterization of a protease-producing bacterium}

Sediment samples were collected from a few aquaculture ponds of fishery farms located in Shanghai, China. Samples were homogenized in nine volumes of a sterilized PBS solution buffer ( $\mathrm{pH}$ 7.4) [35], and microbial cells in supernatant were collected as previously described by Zhang et al. [37]. Serial dilutions were made and spread onto the selective skim milk agar plates, which were incubated at $30^{\circ} \mathrm{C}$ for $48 \mathrm{~h}$. Single colonies were scored positive for protease activity using a skim milk assay in which the isolates form clear zone around their colonies resulting from skim milk hydrolysis are scored as positive in protease activity. Conventional phenotypic and biochemical characterizations were carried out for new isolates according to the Bergey's manual of determinative bacteriology [38] using the microscope (model 36XV, Shanghai Wanheng Precision Instrument Co. Ltd, Shanghai, China) and the bacterial biochemical test kits (Hangzhou Tianhe Microorganism Reagent Co. Ltd., Hangzhou, China). The 16S rRNA gene from the isolate was amplified and sequenced using the bacterial universal primers $27 \mathrm{~F}$ (5'-AGAGTTTGAT CCTGGCTCAG-3') and 1492R (5'-TACCTTGTTACG ACTT-3') [39].

Automated DNA sequencing was carried out using ABI3730XL sequencer (Applied Bio-systems, USA) and BigDye Terminator version 3.1 kit at the China Human Genome Center (Shanghai, China). The sequences were analyzed by the program Bioedit (Version 7.0.9, http:// www.mbio.ncsu.edu/BioEdit) and the Basic Local Alignment Search Tool (BLAST) (http://www.ncbi.nlm.nih. gov/BLAST). Multiple sequence alignments were performed using the ClustalW2 software (http://www.ebi.ac.uk/ Tools/msa/clustalw2/) [40]. The neighbor-joining method in the molecular evolutionary genetic analysis software package MEGA (version 4.0) [41] was used to construct a phylogenetic tree. A bootstrap analysis with 1000 replicates was carried out to check the reliability of the tree. Signal peptide sequences were identified using the SignalP-NN Version 4.0 Server [42]. Oligonucleotide primers were synthesized by Shanghai Sangon Biological Engineering Technology Services Co., Ltd. (Shanghai, China).

\section{PCR amplification of the CtpA gene of the P. lautus CHN26}

Chromosomal DNA was prepared using the MiniBEST Bacteria DNA Extraction Kit Version 2.0. (Japan TaKaRa BIO, Dalian Company, China) according to the protocols described by the manufacture. The concentration of DNA in the samples was determined using a multimode microplate reader BioTek Synergy ${ }^{\mathrm{Ts}} 2$ (BioTek Instruments, Inc., VT, USA). The $c t p A p$ gene of $P$. lautus CHN26 was amplified by PCR with the primer pair ctp1-F (5'-TTGCTGAAAAAACGAACGG-3') and ctp1R (5'-TTACTTGTTCGACGCCTTAGC-3'), which was designed using the software Primer 5.0 (http://www. PremierBiosoft.com) based on the putative C-terminal protease gene sequence of the Paenibacillus sp. Y412MC10 (GenBank: NC_013406.1) in the public database. The PCR amplification was performed according to the method described by Shi et al. [18], except that the primer annealing was set at $59^{\circ} \mathrm{C}$ for $30 \mathrm{~s}$, and elongation at $72^{\circ} \mathrm{C}$ for $90 \mathrm{~s}$. A sample $(5 \mu \mathrm{l})$ of each PCR product was analyzed by agarose gel electrophoresis with a $1.0 \%$ agarose gel. Amplified DNA fragments were visualized under short-wave UV light $(260 \mathrm{~nm})$ and imaged by 
UVEC $_{3}$ Imaging System (UVP LLC, CA, USA). The PCR product was purified using AxyPrep DNA Gel Extraction Kit (Axygen, CA, USA), and ligated into the pGM-T vector according to the method described by Shi et al. (2013). A $100 \mu \mathrm{l}$ of transformation culture was spread onto LB-ampicillin plates containing $40 \mu \mathrm{l}$ 5-bromo-4-chloro-3indolyl- $\beta$-D-galactopyranoside (X-gal, $20 \mathrm{mg} / \mathrm{ml}$ ), and $16 \mu \mathrm{l}$ isopropyl- $\beta$-D-thiogalactoside (IPTG, $50 \mathrm{mg} / \mathrm{ml}$ ). Plates were incubated overnight at $37^{\circ} \mathrm{C}$, and white colonies were randomly picked up for colony PCR analysis. Plasmid DNA was prepared using the MiniBEST Plasmid DNA Extraction Kit Ver.2.0 (TaKaRa).

\section{Expression and purification of CtpAp in E. coli BL21}

Based on the sequence obtained in this study, the primers ctp1-F2 (5'-CCGGAATTCATGTTGACCCAGC3') and ctp1-R2 (5'-CCGCTCGAGCTTGTTCGACG-3') targeting $c t p A p$ structural gene were designed, in which the recognition sites of restriction endonuclease EcoRI and XhoI were marked as italics. The amplified PCR product and the pET-28a plasmid DNA were individually digested with EcoRI and XhoI (TaKaRa), purified, and ligated as previously described by Shi et al. [18]. Ligation DNA was transformed into E. coli BL21 competent cells via the heat-shock method. A $100 \mu \mathrm{l}$ of transformation culture was spread onto each LB agar plate containing $30 \mu \mathrm{g} / \mathrm{ml}$ kanamycin. Plates were incubated overnight at $37^{\circ} \mathrm{C}$, and colony PCR was used for screening positive clones.

The recombinant CtpAp protein was induced and purified as previously described by Shi et al. [18]. The cell lysate was centrifuged at $16,000 \mathrm{~g}$ for $20 \mathrm{~min}$ at $4^{\circ} \mathrm{C}$, and the supernatant containing soluble target protein was collected and analyzed by one-dimensional sodium dodecyl sulfate-polyacrylamide gel electrophoresis (SDSPAGE) with $12 \%$ separation gel and $5 \%$ stacking gel using a Mini-PROTEAN ${ }^{\circ}$ electrophoresis cell (Bio-Rad). Following electrophoresis, the gel was stained with $0.25 \%$ Coomassie brilliant blue R250 and then destained according to the standard method (Sambrook and Russell, 2001). The cell-free extract was purified using Ni-NTA His. Bind $^{\circ}$ resin (Merck Millipore). The resulting protein fractions were collected and analyzed by SDS-PAGE. The purified target protein was concentrated and desalted using the Amicon Ultra-15 centrifugal filter device (EMD Millipore Corporation, MA, USA) according to the instruction of the manufacturer. The E. coli BL21 carrying the vector pET28a was used as a control.

\section{Protease assays}

Cleavage of protein substrates by CtpAp was assayed according to the method described by Spiers et al. [43]. Briefly, $10 \mu \mathrm{l}$ of purified enzyme and $6 \mu \mathrm{g}$ casein substrates $(\beta$-casein from bovine milk, Sigma-Aldrich, MO,
USA; $\alpha$ S1-casein from bovine milk [ $\geq 80 \%]$, Sangon) in $100 \mu \mathrm{l}$ of reaction buffer $(0.05 \mathrm{M}$ Tris- $\mathrm{HCl}, 0.5 \mathrm{mM}$ $\mathrm{MgCl}_{2}, \mathrm{pH}$ 9.0) were incubated at $30^{\circ} \mathrm{C}$ for $0.5-6 \mathrm{~h}$. The reaction products were analyzed by SDS-PAGE. Protease activity was quantitatively measured spectrophotometrically according to the method described by Kasana and Yadav [44]. Briefly, $10 \mu \mathrm{l}$ of purified enzyme was added into $140 \mu \mathrm{l}$ reaction buffer $(0.05 \mathrm{M}$ Tris- $\mathrm{HCl}, 0.5 \mathrm{mM}$ $\mathrm{MgCl}_{2}, \mathrm{pH}$ 9.0) containing $4 \mu \mathrm{l} \beta$-casein. After incubation at $30^{\circ} \mathrm{C}$ for $2 \mathrm{~h}$, the enzyme reaction was terminated by adding $150 \mu \mathrm{l} 10 \%$ trichloroacetic acid (TCA). The reaction mixture was centrifuged at $16,000 \mathrm{~g}$ for $20 \mathrm{~min}$ at $4{ }^{\circ} \mathrm{C}$, and $20 \mu \mathrm{l}$ of supernatant was measured at $562 \mathrm{~nm}$ using a microplate reader Synergy $^{\mathrm{mm}} 2$ (BioTek). One relative activity unit was defined as a 0.01 increase in the $\mathrm{A}_{562}$ after $2 \mathrm{~h}$ at $30^{\circ} \mathrm{C}$ and $\mathrm{pH} 9.0$ (Kim and Lei, 2005).

The cleavage of peptides was examined by reversephase High Performance Liquid Chromatography (HPLC) (model HPX-87P, Bio-Rad, CA, USA). Three oligopeptides were tested for CtpAp cleavage including S-24 (pD1) (Val-Met-His-Glu-Arg-Asn-Ala-His-Asn-Phe-Pro-LeuAsp-Leu-Ala-Ala-Ile-Glu-Ala-Pro-Ser-Thr-Asn-Gly) corresponding to the C-terminal 24 aa of spinach pD1, as well as N15 (Val-Met-His-Glu-Arg-Asn-Ala-His-AsnPhe-Pro-Leu-Asp-Leu-Ala) and C9 (Ala-Ile-Glu-AlaPro-Ser-Thr-Asn-Gly) [45]. These oligopeptides were synthesized in Sangon (Shanghai, China). The assay was performed according to the methods described by Yamamoto et al. [14]. Briefly, $6 \mu$ of purified CtpAp was added into $33 \mu \mathrm{l}$ reaction buffer $(25 \mathrm{mM}$ Hepes- $\mathrm{KOH}$ buffer, $\mathrm{pH}$ 7.7) containing $300 \mu \mathrm{M}$ synthetic peptide substrates, and incubated at $30^{\circ} \mathrm{C}$ for $3 \mathrm{~h}$. The reaction was terminated by addition of $6 \mu \mathrm{l}$ of $18 \%(\mathrm{w} / \mathrm{v}) \mathrm{TCA}$, and then the mixture was kept at the room temperature for $20 \mathrm{~min}$. The yielded products were centrifuged at 20,000 $\mathrm{g}$ for $20 \mathrm{~min}, 35 \mu \mathrm{l}$ of the supernatant was mixed with $145 \mu \mathrm{l}$ of $0.1 \%(\mathrm{v} / \mathrm{v})$ trifluoroacetic acid (TFA), and the mixture was filtered through the $0.22 \mu \mathrm{m}$ Millex-GP (Merck Millipore Corporation, Billerica, MA, USA). The $40 \mu \mathrm{l}$ of the filtrate was analyzed by HPLC analysis with a Vydac $218 \mathrm{TP}^{\mathrm{mm}} \mathrm{C}_{18}$ reversed-phase column (4.6 mm i.d. $\times$ $25 \mathrm{~cm}, 5 \mu \mathrm{m}$ particle size with $300 \AA$ pore diameter silica) with a linear gradient of $0.2-80 \%$ acetonitrile with $0.1 \%$ TFA (w/v) at a flow rate of $1 \mathrm{ml} / \mathrm{min}$ over $25 \mathrm{~min}$. The peptide peaks were detected at a wavelength of $214 \mathrm{~nm}$ in a Photo-Diode Array detector.

Haemolysis assay was performed according to the method described by Mitchell and Minnick [27] by streaking E. coli BL21 containing pET-28a-ctpAp onto blood agar plates. After incubation overnight at $37^{\circ} \mathrm{C}$, the plates were observed visually for clear zones of haemolysis. E. coli BL21 carrying pET28a was used as the control. 


\section{Sequencing of peptides resulting from $P$. lautus $C \operatorname{tpA}$ digestions on casein substrates}

Mass spectra of peptide fragment ions, produced by CtpAp cleavage of casein substrates, were determined using the 4800 Plus MALDI TOF/TOF ${ }^{\mathrm{m}}$ Analyzer (Applied Biosystems, CA, USA) at Proteomics Center of Fudan University (Shanghai, China). After cleavage, the digestion products were purified by the CapTrap ${ }^{\text {ma }}$ Peptide column $(0.5 \mathrm{~mm}$ i.d. $\times 2 \mathrm{~mm}$, Michrom Bioresources, CA, USA) at a $20 \mu \mathrm{l} / \mathrm{min}$ flow rate with solvent A (5\% acetonitrile, $95 \% \mathrm{H}_{2} \mathrm{O}, 0.1 \%$ formic acid) for $5 \mathrm{~min}$, and then separated by the Magic $\mathrm{C}_{18}$ AQ column $(0.1 \mathrm{~mm}$ i.d. $\times$ $15 \mathrm{~cm}, 5 \mu \mathrm{m}$ particles with $200 \AA$ pore size, Michrom) with a linear gradient of 5 to $45 \%$ solvent B ( $90 \%$ acetonitrile, $10 \% \mathrm{H}_{2} \mathrm{O}, 0.1 \%$ formic acid) with solvent $\mathrm{A}$ over $70 \mathrm{~min}$ at a $500 \mu \mathrm{l} / \mathrm{min}$ flow rate. The purified samples were subjected to the analysis with MALDI-TOF/TOF Analyzer according to the instructions of the manufacturer.

\section{Characterization of $P$. lautus CtpA enzyme}

Purified CtpAp was subjected to several biochemical assays including optimum temperature and $\mathrm{pH}$, and effects of metal ions, inhibitors and organic solvents on enzyme stability. The data was expressed as an average of the results from triplicate assays. The optimum temperature for enzyme activity was determined at temperature range of 10 to $80^{\circ} \mathrm{C}$ at $\mathrm{pH} 9.0$ using $\beta$-casein as the substrate. The thermostability of CtpAp was assayed by incubating aliquots of purified CtpAp at 10 to $80^{\circ} \mathrm{C}$ for $3 \mathrm{~h}$. The residual activities were measured at $30^{\circ} \mathrm{C}$. The effect of $\mathrm{pH}$ on enzyme activity was examined at $30^{\circ} \mathrm{C}$ at various $\mathrm{pH}$ values between 3.0 to $11.0[14,18]$. The $\mathrm{pH}$ stability of the enzyme was assayed by incubating CtpAp at $\mathrm{pH} 3.0-10.0$ at $4^{\circ} \mathrm{C}$ for $12 \mathrm{~h}$. The residual enzyme activity was determined under standard condition at $30^{\circ} \mathrm{C}$ and $\mathrm{pH} 9.0$ using the $\beta$-casein substrate.

The effects of metal ions (1-10 mM), detergents $(0.1$ $0.5 \%)$, inhibitors (1-10 $\mathrm{mM})$ and organic solvents $(1-10 \%)$ on enzyme stability were examined by individually incubating aliquots of purified CtpAp with different reagents at $30^{\circ} \mathrm{C}$ for $1 \mathrm{~h}$, and the residual enzyme activity was determined under standard condition as described above.

\section{Competing interests}

The authors declare that they have no competing interests.

\section{Authors' contributions \\ $Y L$, YP and LC participated in the design of the study; $Y L$ carried out the major experiments, YL and LC analyzed the data; LC drafted the manuscript, and $Q S$ revised it for important intellectual content and improvement; $Y L$, $Y P, Q S$ and $L C$ read and approved the final manuscript to be published.}

\section{Acknowledgements}

This work was supported by Grants No.09320503600 and No.10PJ1404900 from Shanghai Municipal Science and Technology Commission, a Grant No.B-9500-10-0004 and a Leading Academic Discipline Project (No. J50704) from Shanghai Municipal Education Commission, and a Grant No.31271830 from National Natural Science Foundation of China.

\begin{abstract}
Author details
'Key Laboratory of Quality and Safety Risk Assessment for Aquatic Products on Storage and Preservation (Shanghai), China Ministry of Agriculture, Engineering Centre for Quality Control and Risk Assessment of Aquatic Products, College of Food Science and Technology, Shanghai Ocean University, 999 Hu Cheng Huan Road, Shanghai 201306, People's Republic of China. ${ }^{2}$ Department of Biology, University of Copenhagen, Ole Maaløes Vej 5, Copenhagen DK-2200N, Denmark.
\end{abstract}

Received: 12 August 2013 Accepted: 17 October 2013

Published: 25 October 2013

\section{References}

1. Satoh K, Yamamoto Y: The carboxyl-terminal processing of precursor D1 protein of the photosystem II reaction center. Photosynth Res 2007, 94(2-3):203-215.

2. Inagaki N, Maitra R, Satoh K, Pakrasi HB: Amino acid residues that are critical for in vivo catalytic activity of CtpA, the carboxyl-terminal processing protease for the D1 protein of photosystem II. J Biol Chem 2001, 276(32):30099-30105.

3. Liao DI, Qian J, Chisholm DA, Jordan DB, Diner BA: Crystal structures of the photosystem II D1 C-terminal processing protease. Nature Struct Biol 2000, 7(9):749-753.

4. Hara H, Yamamoto $Y$, Higashitani A, Suzuki H, Nishimura Y: Cloning, Mapping, and characterization of the Escherichia coli prc gene, which is involved in C-terminal processing of penicillin-binding protein 3. J Bacteriol 1991, 173(15):4799-4813.

5. Silber KR, Keiler KC, Sauer RT: Tsp: A tail-specific protease that selectively degrades proteins with nonpolar C termini. Proc Natl Acad Sci USA 1992, 89(1):295-299

6. Keiler KC, Silber KR, Downard KM, Papayannopoulos IA, Biemann K, Sauer RT: C-terminal specific protein degradation: activity and substrate specificity of the Tsp protease. Protein Sci 1995, 4(8):1507-1515.

7. Oelmuller R, Herrmann RG, Pakrasi HB: Molecular studies of CtpA, the carboxyl-terminal processing protease for the $\mathrm{D} 1$ protein of the photosystem II reaction center in higher plants. J Biol Chem 1996, 271(36):21848-21852.

8. Shestakov SV, Anbudurai PR, Stanbekova GE, Gadzhiev A, Lind LK, Pakrasi HB: Molecular cloning and characterization of the ctpA gene encoding a carboxyl-terminal processing protease: analysis of a spontaneous photosystem II-deficient mutant strain of the cyanobacterium Synechocystis sp. PCC 6803. J Biol Chem 1994, 269(30):19354-19359.

9. Wang $\mathrm{CY}$, Wang SW, Huang WC, Kim KS, Chang NS, Wang YH, Wu MH, Teng CH: Prc contributes to Escherichia coli evasion of classical complement-mediated serum killing. Infect Immun 2012, 80(10):3399-3409.

10. Kumru OS, Bunikis I, Sorokina I, Bergstrom S, Zuckert WR: Specificity and role of the Borrelia burgdorferi CtpA protease in outer membrane protein processing. J Bacteriol 2011, 193(20):5759-5765.

11. Dong J, Signo KS, Vanderlinde EM, Yost CK, Dahms TE: Atomic force microscopy of a ctpA mutant in Rhizobium leguminosarum reveals surface defects linking CtpA function to biofilm formation. Microbiology 2011, 157(11):3049-3058.

12. Bandara AB, Sriranganathan N, Schurig GG, Boyle SM: Carboxyl-terminal protease regulates Brucella suis morphology in culture and persistence in macrophages and mice. J Bacteriol 2005, 187(16):5767-5775.

13. Bandara AB, DeShazer D, Inzana TJ, Sriranganathan N, Schurig GG, Boyle SM: A disruption of CtpA encoding carboxy-terminal protease attenuates Burkholderia mallei and induces partial protection in CD1 mice. Microb Pathog 2008, 45(3):207-216.

14. Yamamoto Y, Inagaki N, Satoh K: Overexpression and characterization of carboxyl-terminal processing protease for precursor D1 protein: regulation of enzyme-substrate interaction by molecular environments. J Biol Chem 2001, 276(10):7518-7525.

15. Rao MB, Tanksale AM, Ghatge MS, Deshpande W: Molecular and biotechnological aspects of microbial proteases. Microbiol Mol Biol Rev 1998, 62(3):597-635.

16. Krik O, Borchert TV, Fuglsang CC: Industrial enzyme applications. Curr Opin Biotechnol 2002, 13(4):345-435. 
17. Sharmaa R, Chistib Y, Banerjee UC: Production, purification, characterization, and applications of lipases. Biotechnol Adv 2001, 19:627-662.

18. Shi Y, Pan Y, Li B, He W, She Q, Chen L: Molecular cloning of a novel bioH gene from an environmental metagenome encoding a carboxylesterase with exceptional tolerance to organic solvents. BMC Biotechnol 2013, 13:13.

19. Lal S, Tabacchioni S: Ecology and biotechnological potential of Paenibacillus polymyxa: a minireview. Indian J Microbiol 2009, 49(1):2-10.

20. Choi KK, Park CW, Kim SY, Lyoo WS, Lee SH, Lee JW: Polyvinyl alcohol degradation by Microbacterium barkeri KCCM 10507 and Paeniblacillus amylolyticus KCCM 10508 in dyeing wastewater. J Microbiol Biotechnol 2004, 14:1009-1013.

21. Konishi J, Maruhashi K: 2-(2'-Hydroxyphenyl)benzene sulfinate desulfinase from the thermophilic desulfurizing bacterium Paenibacillus sp. strain A11-2: purification and characterization. Appl Microbiol Biotechnol 2003, 62:356-361

22. Girardin H, Albagnac C, Dargaignaratz C, Nguyen-The C, Carlin F: Antimicrobial activity of foodborne Paenibacillus and Bacillus spp. against Clostridium botulinum. J Food Prot 2002, 65:806-813.

23. Lu F, Lu Z, Bie X, Yao Z, Wang Y, Lu Y, Guo Y: Purification and characterization of a novel anticoagulant and fibrinolytic enzyme produced by endophytic bacterium Paenibacillus polymyxa EJS-3. Thromb Res 2010, 126(5):349-355.

24. Heyndrickx M, Vandemeulebroecke K, Scheldeman P, Kersters K, De Vos P, Logan NA, Aziz AM, Ali N, Berkeley RCW: A polyphasic reassessment of the genus Paenibacillus, reclassification of Bacillus lautus (Nakamura 1984) as Paenibacillus lautus comb. nov. and of Bacillus peoriae (Montefusco et al. 1993) as Paenibacillus peoriae comb. nov., and emended descriptions of P. lautus and of $P$. peoriae. Int J Syst Bacteriol 1996, 46:988-1003.

25. Mead DA, Lucas S, Copeland A, Lapidus A, Cheng J-F, Bruce DC, Goodwin LA, Pitluck S, Chertkov O, Zhang X, Detter JC, Han CS, Tapia R, Land M, Hauser LJ, Chang Y-J, Kyrpides NC, Ivanova NN, Ovchinnikova G, Woyke T, Brumm C, Hochstein R, Schoenfeld T, Brumm P: Complete Genome Sequence of Paenibacillus strain Y4.12MC10, a Novel Paenibacillus lautus strain Isolated from Obsidian Hot Spring in Yellowstone National Park. Stand Genomic Sci 2012, 6:366-385.

26. Zhou R, Kroos L: Serine proteases from two cell types target different components of a complex that governs regulated intramembrane proteolysis of pro-sigmaK during Bacillus subtilis development. Mol Microbiol 2005, 58(3):835-846.

27. Mitchell SJ, Minnick MF: A carboxy-terminal processing protease gene is located immediately upstream of the invasion-associated locus from Bartonella bacilliformis. Microbiology 1997, 143(4):1221-1233.

28. Ostberg Y, Carroll JA, Pinne M, Krum JG, Rosa P, Bergstrom S: Pleiotropic effects of inactivating a carboxyl-terminal protease, CtpA, in Borrelia burgdorferi. J Bacteriol 2004, 186(7):2074-2084

29. Hoge $R$, Laschinski M, Jaeger KE, Wilhelm S, Rosenau F: The subcellular localization of a C-terminal processing protease in Pseudomonas aeruginosa. FEMS Microbiol Lett 2011, 316(1):23-30.

30. Jimenez-Flores R, Kang YC, Richardson T: Cloning and sequence analysis of bovine beta-casein CDNA. Biochem Biophys Res Commun 1987 142(2):617-621.

31. Gorodetskii SI, Zakhar'ev VM, Kyarshulite DR, Kapelinskaya TV, Skryabin KG: Cloning and nucleotide sequence of cDNA for bovine alphaS1-casein. Biochem USSR 1987, 51(10-1):1402-1409.

32. Taguchi F, Yamamoto $Y$, Satoh K: Recognition of the structure around the site of cleavage by the carboxyl-terminal processing protease for D1 precursor protein of the photosystem II reaction center. J Biol Chem 1995, 270(18):10711-10716.

33. Fabbri BJ, Duff SM, Remsen EE, Chen YC, Anderson JC, CaJacob CA: The carboxyterminal processing protease of D1 protein: expression, purification and enzymology of the recombinant and native spinach protein. Pest Manag Sci 2005, 61(7):682-690.

34. Rai S, Mukherjee A: Statistical optimization of production, purification and industrial application of a laundry detergent and organic solvent-stable subtilisin-like serine protease (Alzwiprase) from Bacillus subtilis DM-04. Biochem Eng J 2010, 48(2):173-180.

35. Sambrook J, Russell DW: Molecular Cloning: A Laboratory Manual. New York: Cold Spring Harbor Press; 2001
36. Saran S, Isar J, Saxena RK: A modified method for the detection of microbial proteases on agar plates using tannic acid. J Biochem Biophys Methods 2007, 70(4):697-699.

37. Zhang T, Pan Y, Li L, Ou J, Zhang J, Chen Y, Peng X, Chen L: Molecula cloning and antimicrobial activity of enterolysin $A$ and helveticin $J$ of bacteriolysins from metagenome of Chinese traditional fermented foods. Food Control 2013, 31(2):499-507.

38. Holt JG: Bergey's Manual of Determinative Bacteriology. Ninthth edition. Philedelphia: Lippincott Williams \& Wilkins; 1994.

39. Weisburg WG, Barns SM, Pelletier DA, Lane DJ: 16S ribosomal DNA amplification for phylogenetic study. J Bacteriol 1991, 173:697-703.

40. Larkin MA, Blackshields G, Brown NP, Chenna R, NcGettigan PA, McWilliam $H$, Valentin F, Wallace IM, Wilm A, Lopez R, Thompson JD, Gibson TJ, Higgins DG: Clustal W and Clustal X version 2.0. Bioinformatics 2007, 23:2947-2948

41. Tamura K, Dudley J, Nei M, Kumar S: MEGA4: Molecular evolutionary genetics analysis (MEGA) software version 4.0. Mol Biol Evol 2007, 24(8):1596-1599.

42. Kall L, Krogh A, Sonnhammer EL: A combined transmembrane topology and signal peptide prediction method. J Mol Biol 2004, 338(5):1027-1036.

43. Spiers A, Lamb HK, Cocklin S, Wheeler KA, Budworth J, Dodds AL, Pallen MJ, Maskell DJ, Charles IG, Hawkins AR: PDZ domains facilitate binding of high temperature requirement protease $\mathrm{A}(\mathrm{H} \operatorname{tr} \mathrm{A})$ and tail-specific protease (Tsp) to heterologous substrates through recognition of the small stable RNA A (ssrA)-encoded peptide. J Biol Chem 2002, 277(42):39443-39449.

44. Kasana RC, Yadav SK: Isolation of a psychrotrophic Exiguobacterium sp. SKPB5 (MTCC 7803) and characterization of its alkaline protease. Curr Microbiol 2007, 54(3):224-229.

45. Yamamoto $Y$, Satoh K: Competitive inhibition analysis of the enzymesubstrate interaction in the carboxy-terminal processing of the precursor D1 protein of photosystem II reaction center using substituted oligopeptides. FEBS Lett 1998, 430(3):261-265.

doi:10.1186/1472-6750-13-89

Cite this article as: Li et al:: A novel carboxyl-terminal protease derived from Paenibacillus lautus CHN26 exhibiting high activities at multiple sites of substrates. BMC Biotechnology 2013 13:89.

\section{Submit your next manuscript to BioMed Central and take full advantage of:}

- Convenient online submission

- Thorough peer review

- No space constraints or color figure charges

- Immediate publication on acceptance

- Inclusion in PubMed, CAS, Scopus and Google Scholar

- Research which is freely available for redistribution 